\title{
KEBIJAKAN PENGELOLAAN SUMBER DAYA IKAN KAKAP MERAH (Lutjanus spp.) DI LAUT ARAFURA
}

\author{
Budi Iskandar Prisantoso dan Badrudin \\ Peneliti pada Pusat Penelitian Pengelolaan Perikanan dan Konservasi Sumber Daya Ikan, Ancol-Jakarta \\ Teregistrasi I tanggal: 9 April 2010; Diterima setelah perbaikan tanggal: 20 April 2010; \\ Disetujui terbit tanggal: 30 April 2010
}

\begin{abstract}
ABSTRAK
Sumber daya ikan kakap merah di Laut Arafura secara efektif dimanfaatkan oleh perikanan rawai dasar dan pukat ikan skala industri. Pukat udang dengan target penangkapan udang tertangkap juga sejumlah besar ikan demersal, di mana ikan kakap merah (Lutjanus spp.) berukuran kecil sering tertangkap dalam jumlah yang sedikit. Melaui kajian genetic similarity Australia menyimpulkan bahwa ikan kakap merah di kedua sektor Laut Arafura tersebut merupakan satu unit stok yang dikelola secara bersama melalui kerangka kerja IndonesiaAustralia shared snapper management plan. Secara ekonomi, langkah pengelolaan bersama tersebut mempunyai implikasi luas yang berpotensi merugikan Indonesia. Hasil analisis data dan informasi lanjutan menemukan bahwa populasi ikan kakap merah di kedua sektor perairan Laut Arafura merupakan unit-unit stok yang terpisah dengan cakupan kawasan perairan yang sangat luas (mega separate stock). Dengan demikian stok ikan kakap merah di kedua sektor Laut Arafura tersebut dapat dikelola sesuai dengan yurisdiksi, kebijakan, dan tujuan pengelolaan yang ditetapkan oleh masing-masing negara.
\end{abstract}

KATA KUNCl: $\quad$ stok ikan kakap merah, Laut Arafura, pengelolaan bersama

ABSTRACT: Management measures for red snapper resources in the Arafura Sea. By: Budi Iskandar Prisantoso and Badrudin

Red snapper resources in the Arafura Sea have been effectively exploited by the industrial scale of bottom long line, fish trawl, and shrimp trawl fisheries. A substantial mount of demersal fish caught by the shrimp trawl fisheries in which a small size (juvenile) red snapper species was also retained. Through genetic similarity studies Australia concluded that the red snapper stock in both sector of the Arafura Sea belong to one stock unit and should collaborative managed under the framework of Indonesia-Australia shared snapper management plan. Based on the economic aspect this management has a wide implication that lead to some potential losses to Indonesia. Further studies on some population dynamics aspects and analysis of the available data and information it was found that the red snapper stocks in the two sectors of the Arafura Sea provide a mega separate stock, occupying a very wide waters area. Based on these findings it can be stated that management of these mega separate stock could be managed in accordance with their respective jurisdictions, policies, and management objectives set up by the respective countries.

KEYWORDS: red snappers stock, Arafura Sea, collaborative management 


\section{PENDAHULUAN}

Perairan paparan Laut Arafura yang dangkal merupakan salah satu daerah penangkapan yang paling produktif di Indonesia, karena perairan tersebut secara regular diduga diperkaya oleh nutrient rich upwelling dari Laut Banda dan tambahan nutrien dari sungai-sungai yang bermuara yang berasal dari kawasan terrestrial Papua dengan hutan mangrove yang padat. Kondisi ini yang diduga merupakan pemicu suburnya perairan Laut Arafura sektor Indonesia yang mengakibatkan berkembangnya populasi sumber daya ikan demersal termasuk kelompok ikan kakap merah.

Laut Arafura merupakan bagian dari Paparan Sahul di mana sebagian perairannya merupakan perairan yang termasuk ke dalam wilayah pengelolaan perikanan Indonesia-718 dan sebagian lagi merupakan perairan shelf Australia yang cukup luas. Kegiatan penangkapan demersal di LautArafura dan Laut Timor oleh kapal Taiwan dan Thailand dengan lisensi dari Darwin, sudah berjalan sejak tahun 1970-an. Sampai tahun 1990 sumber daya ikan demersal di perairan shelf Australia telah dieksploitasi secara intensif oleh kapal ikan dari Jepang, Taiwan, dan Thailand. Informasi yang telah diperoleh antara lain komposisi jenis, upaya penangkapan, dan status pemanfaatan (Ramm \& Xiao, 1994; Ramm, 1994). Jenis ikan yang menjadi sasaran antara lain ikan kakap merah (snappers, Lutjanidae), lencam (emperors, Lethrinidae), kuwe (trevallies, Carangidae), dan kurisi (threadfin bream, Nemipteridae).

Dari catatan historis hasil tangkapan kapal Taiwan di perairan Australian Fishing Zone, diperoleh informasi bahwa produksi ikan kakap merah pada tahun 1988 sekitar 1.019 ton, dan pada tahun berikutnya turun drastis menjadi hanya 39 ton (Ramm,
1996). Karena menurun drastisnya hasil tangkapan tersebut, mulai tahun 1990, perikanan demersal tersebut dikatakan sebagai fully exploited dan mulai saat itu pula pemberian lisensi penangkapan ikan bambangan untuk semua kapal penangkap dihentikan (Anonymous, 1999). Keadaan ini didasari atas adanya kekhawatiran terjadinya over exploitasi terhadap stok karena jika benar bahwa stok tersebut merupakan stok bersama akan langsung berpengaruh terhadap stok ikan yang ada di perairan Laut Arafura sektor Indonesia.

Data dan informasi yang dianalisis merupakan sebagian hasil kerja sama penelitian antara Indonesia-Australia yang dilaksanakan oleh Pusat Riset Perikanan Tangkap-ACIAR antara tahun 1999-2003. Sejumlah data tambahan sebagai up dating telah diikutsertakan dalam analisis terutama setelah tahun 2007 sampai saat ini. Data catch dan effort dari perikanan rawai dasar asal Tanjung Balai Karimun telah dikumpulkan dari sub basis penangkapan di Kupang pada tahun 2007 dan Probolinggo pada pertengahan tahun 2009. Sejumlah data dan informasi tentang aspek biologi dan dinamika populasi yang dianalisis lebih lanjut berasal dari sejumlah laporan intern, lokakarya, dan publikasi yang disusun sebagai output dari kegiatan kerja sama Indonesia-Australia tersebut (Blaber et al., 2005; Fry et al., 2009).

\section{SUMBER DAYA IKAN KAKAP MERAH}

Ikan kakap merah atau bambangan adalah salah satu jenis ikan demersal ekonomis penting yang cukup banyak tertangkap di perairan Indonesia. Jenis ikan tersebut tertangkap di perairan paparan. Beberapa jenis di antaranya berada pada habitat perairan yang sedikit berkarang (Talbot, 1960). Seluruh jenis ikan kakap merah merupakan anggota famili Lutjanidae. Yang disebut ikan kakap merah adalah 
jenis-jenis ikan dari famili Lutjanidae yang berwarna merah kekuningan sampai merah gelap kehitaman yang merupakan anggota genera Lutjanus dan Pinjalo yang di daerah lain di luar Jawa mempunyai nama lokal tersendiri. Lutjanus malabaricus di Sumbawa Besar disebut ikan kakap asli, Lutjanus bohar (Njalu), Lutjanus sebae (Kemonca), Lutjanus argentimaculatus (jarang gigi), dan Lutjanus gibbus (dapa), dan jenis kakap merah lainnya disebut bambangan. Dalam statistik perikanan nasional, ikan kakap merah dimasukan ke dalam satu kelompok. Sejumlah spesies yang ditemukan di lapangan paling tidak ada sekitar 15 spesies dengan berbagai nama lokal yang berbeda (Tabel 1). Jenis ikan lainnya dari famili Lutjanidae yang juga berukuran besar dan berwarna kuningperak-kemerahan antara lain Pristipomoides spp., Symphorus spp., Aprion spp., dan Etelis spp., yang kesemuanya itu tidak tercatat dalam statistik. Pristipomoides spp., di kawasan timur Indonesia disebut anggoli (berasal dari Ang koh li, dari Malaysia-Singapura). Jenisjenis ikan tersebut sering tertangkap di perairan yang relatif lebih dalam sampai sekitar 200-300 m.

Sejalan dengan makin meningkatnya permintaan akan ikan kakap dan sejenisnya baik secara lokal, dalam negeri maupun luar negeri, maka usaha peningkatan produksi perlu didukung oleh penelitian tentang stok dan cara-cara pemanfaatan bagi diperolehnya hasil tangkapan yang optimal dan berlanjut. Usaha pemanfaatan sumber daya ikan di perairan Zona Ekonomi Ekslusif Indonesia Laut Arafura atau Laut Timor yang merupakan perairan transboundary yang dilakukan secara optimal dan berlanjut selain merupakan usaha pemanfaatan potensi wilayah bagi peningkatan kesejahteraan juga dalam rangka memenuhi kewajiban internasional dan memperkokoh prinsip Wawasan Nusantara.

Tabel 1. Jenis-jenis ikan yang dikatagorikan sebagai kakap merah Table 1. Species catagories as red snapper

\begin{tabular}{clll}
\hline No. & \multicolumn{1}{c}{$\begin{array}{c}\text { Nama ilmiahl } \\
\text { Scientific name }\end{array}$} & \multicolumn{1}{c}{$\begin{array}{c}\text { Nama Inggrisl } \\
\text { English name }\end{array}$} & $\begin{array}{c}\text { Nama lokall } \\
\text { Local name }\end{array}$ \\
\hline 1. & Lutjanus malabaricus & Malabar blood snapper & Kakap asli \\
2. & Lutjanus gibbus & Humpback red snapper & Dapa \\
3. & Lutjanus erythropterus & Crimson snapper & Bambangan \\
4. & Lutjanus bohar & Two spot red snapper & Njalu \\
5. & Lutjanus sebae & Emperor red snapper & Kemonca \\
6. & Lutjanus argentimaculatus & Mangrove red snapper & Jarang gigi \\
7. & Lutjanus johnii & John's snapper & Jenaha \\
8. & Lutjanus bitaeniatus & Indonesian snapper & Kakap merah \\
9. & Lutjanus timorensis & Timor snapper & Kakap merah \\
10. & Lutjanus monostigma & One spot snapper & Kakap merah \\
11. & Pinjalo pinjalo & Pinjalo & Kakap merah \\
12. & Pristipomoides multidens & Gold band snapper & Anggoli, Kurisi bali \\
13. & Pristipomoides typus & Sharptooth jobfish & Kurisi bali \\
14. & Pristipomoides filamentosus & Randall snapper & Kurisi bali \\
15. & Etelis carbunculus & Ruby snapper & Guntur \\
\hline
\end{tabular}

Sumber/Sources:Badrudin \& Aisyah (2009) 


\section{Tingkat Pemanfaatan}

Terdapat tiga jenis ikan kakap merah di Laut Arfaura sektor Indonesia yaitu Lutjanus malabaricus, Lutjanus erythropterus, dan Pristipomoides Multidens dan berdasarkan atas analisis genetik menunjukan bahwa ketiga jenis tersebut memiliki kesamaan (genetic similarity). Parameter populasi dari tiga spesies ikan kakap merah tersebut dengan titik acuan (reference point) biomassa tahun 1990, maka berbagai skenario dinamika biomassa dan total hasil tangkapan tahunan yang merupakan salah satu opsi langkah pengelolaan telah disusun oleh Blaber et al. (2005) sebagai berikut:

\section{Opsi pesimistik}

Untuk opsi yang pesimistik, hasil tangkapan pada tahun 2002 sebesar 4.000 ton, maka tingkat biomassa sekitar $11 \%$ dari limit reference point (biomassa pada tahun 1990) dan oleh karenanya biomassa ikan kakap merah akan mengalami collapse is underway (mulai tahun 2006/2007) terutama jika hasil tangkapan yang tinggi tetap dipertahankan.

\section{Opsi optimistik}

Opsi optimistik adalah hasil diupayakan tangkapan 2.000 ton pada tahun 2002, di mana tingkat biomassa sekitar 31\% dari tingkat biomassa tahun 1990. Jika hasil tangkapan mendatang dipertahankan pada tingkat saat ini, maka kondisi menurunnya biomassa sumber daya ikan kakap merah akan perlahan-lahan dan pada tahun 2010 biomassa hanya sekitar 23\% dari biomassa tahun 1990. Walaupun di bawah skenario yang optimistik sekalipun, pulihnya biomassa akan terjadi jika hasil tangkapan yang ditetapkan hanya sekitar 1.500 ton. Untuk mempercepat pulihnya biomassa sampai pada tingkat biomassa tahun 1990 secara signifikan tampaknya hanya dapat dilakukan melalui penutupan perikanan sampai 10 tahun ke depan.

Berdasarkan atas perhitungan yang dilakukan dari jumlah kapal, trip dan ratarata hasil tangkapan ikan kakap merah per kapal per trip, skenario hasil tangkapan yang optimistik adalah setara dengan 1.303 ton di Indonesia, sedangkan estimasi model dinamika biomasaa 1.488 ton (Blaber et al., 2005). Kondisi tersebut dapat berlaku jika asumsi populasi ikan kakap merah di Laut Arafura sektor Indonesia dan Australia merupakan satu unit stok. Dari hasil penelitian biologi dan dinamika populasi ketiga spesies ikan kakap merah menunjukan bahwa populasi ikan kakap merah di Laut Arafura sektor Indonesia dan Australia diduga tidak merupakan satu unit stok. Menurut Lloyd et al. (1996), stok ikan anggoli (Gold band snapper) di Laut Arafura merupakan mega separate stock. Pernyataan biomassa bahwa collapse is underway pada tahun 2006/2007 diduga terlalu dini. Hal ini dapat dibandingkan dengan data hasil tangkapan rawai dasar asal Tanjung Balai Karimun yang dicatat di sub basis Kupang, di mana total hasil tangkapan kelompok ikan kakap merah 1.673,5 ton (Badrudin \& Aisyah, 2009). Hasil tangkapan tersebut baru yang tercatat di Kupang, belum termasuk ikan kakap merah yang tertangkap dengan fish net yang didaratkan di Merauke, Tual, Ambon, atau yang di transshipment dari kapal penangkap (catcher) ke kapal pengangkut (carrier), yang jumlahnya tidak diketahui.

Data hasil tangkapan rawai dasar asal Tanjung Balai Karimun yang beroperasi di Laut Arafura yang didaratkan atau dicatat di sub basis Probolinggo pada tahun 2008 dan sampai bulan Agustus 2009 dapat dipastikan bahwa collapse-nya biomassa sumber daya ikan kakap merah belum akan terjadi dalam waktu satu atau dua tahun ke 
depan ini. Selanjutnya dijelaskan bahwa ikan kakap merah yang hanya merupakan hasil tangkapan rawai dasar asal Tanjung Balai Karimun yang tercatat oleh agen perusahaan di Probolinggo pada tahun 2008 sudah tercatat 1.672 ton, dan pada tahun 2009 sampai bulan Agustus, hasil tangkapan ikan kakap merah sudah mencapai sekitar 1.523 ton. Hasil tangkapan ikan kakap merah dari Laut Arafura tersebut belum termasuk ikan kakap merah yang didaratkan di Ambon, Tual, Sorong, dan Merauke (sebagai bycatch) serta hasil tangkapan perikanan skala kecil yang didaratkan di tempat lainnya.

Tampak jelas bahwa apa yang dikhawatirkan oleh pihak Australia yaitu collapse-nya perikanan ikan kakap merah di Laut Arafura tidak terjadi. Hal ini disebabkan karena asumsi dasar bahwa sumber daya ikan kakap merah di Laut Arafura merupakan satu unit stok ternyata tidak terpenuhi, seperti spawning ground yang banyak menyebar di kedua sektor perairan, dan parameter populasi yang sangat berbeda yang diduga erat kaitannya dengan perbedaan tingkat kesuburan perairan antara sektor Indonesia dan Australia.

\section{Pilihan Pengelolaan}

Dalam rancangan Management Plan for the Shared Stock of Red Snappers in Australian and Indonesian Waters (bulan April 2007) dikatakan bahwa langkahlangkah prioritas dalam pengelolaan ikan kakap merah bagi Australia dan Indonesia sebagai berikut:

1. Malarang alat tangkap yang merusak, seperti penggunaan bahan peledak, potassium sianid dalam kegiatan penangkapan ikan.
2. Meminimumkan praktek penangkapan illegal, unreported, unregulated seperti kapal penangkap yang tak berizin, transshipment di tengah laut tanpa melapor.

3. Mengembangkan dan/atau mempertahankan mekanisme yang tepat untuk mengendalikan tingkat hasil tangkapan, seperti pembatasan subsidi bahan bakar.

4. Mengendalikan kapasitas penangkapan melalui:

a. Membatasi ukuran kapal secara memadai pada tingkat gross tonage tertentu.

b. Menjamin ukuran mata jaring trawl (fish net) paling kecil $10 \mathrm{~cm}$ untuk menurunkan tertangkapnya ikan ukuran pre spawning.

c. Membatasi jumlah unit pancing dan bubu. Sebagaimana diketahui dewasa ada kecenderungan makin banyaknya jumlah mata pancing rawai dasar yang dioperasikan (tahun 2000-an hanya sekitar 1.700-2.000an, tahun 2008-2009 sudah lebih dari 3.000-an mata pancing, sehingga hook rate makin menurun.

5. Menetapkan perlunya penutupan daerah dan musim untuk melindungi kawasan asuhan dan pre adult. Kawasan sampai kedalaman 10-an $\mathrm{m}$ dan muara sungai merupakan nursery ground pada musimmusim tertentu.

6. Penutupan daerah penangkapan menutup seluruh atau sebagian perikanan untuk melindungi tingkat biomassa spawning stock.

7. Proteksi habitat menetapkan kawasan pengelolaan bagi habitat yang sangat 
penting bagi ikan kakap merah, misalnya daerah pemijahan (spawning ground) ataupun daerah asuhan (nursery ground).

8. Membatasi perdagangan (pengendalian pasar) ikan yang belum disyahkan untuk ditangkap sesuai dengan rencana pengelolaan. Ukuran ikan kakap merah yang belum mencapai 30-an cm, karena belum mencapai matang gonad.

9. Menerapkan alat pengurang hasil tangkap sampingan (bycatch reduction devices) dan/atau alat pemisah penyu (turtle exclusion devices) pada jaring trawl. Sebagaimana diketahui para nelayan dengan berbagai alasan seperti kurang praktis/ menghambat kelancaran kerja dalam penarikan jarring ke atas dek kapal.

Dari aspek konservasi ke sembilan langkah tersebut sangat efektif, yaitu hanya berdasarkan atas hasil penelitian tiga spesies ikan kakap merah (Lutjanus malabaricus, Lutjanus erythropterus, dan Pristipomoides multidens) lalu menetapkan langkah pengelolaan untuk ke 15 spesies ikan kakap merah bahkan untuk keseluruhan sumber daya ikan demersal yang tidak kurang dari 100 spesies. Memang, karena sifat perikanan demersal yang multi species multi gear, setiap langkah pengelolaan tersebut akan selalu dihadapkan kepada sejumlah kendala. Kendala utama adalah ditetapkannya tujuan pembangunan perikanan yaitu pemanfaatan sumber daya yang optimal dan berlanjut. Langkah optimasi akan selalu dihadapkan kepada sejumlah pilihan termasuk adanya korbanan (trade off), Karena tidak mungkin semua tujuan pengelolaan dapat dicapai secara optimal. Misalnya tujuan mendapatkan keuntungan ekonomi yang maksimum akan bertentangan dengan tujuan penyerapan tenaga kerja yang maksimum. Selain itu, meskipun kegiatan perikanan di Laut Arafura didominansi oleh skala industri, kegiatan penangkapan ikan skala kecil dapat dijumpai di perairanperairan sekitar Merauke, Kepulauan Kai, Dolak, Kaimana, Tembagapura, dan lain-lain yang tentunya ditingkatkan kontribusinya dalam upaya penanggulangan kemiskinan (poverty alleviation) dan ketahanan pangan (food security) (Food and Agriculture Organization, 2009).

Beberapa di antara ke sembilan langkah pengelolaan tersebut sebenarnya sudah dilakukan pihak Indonesia dan memang karena keterbatasan data dasar yang tersedia terutama langkah yang menyangkut penutupan perikanan belum dapat dilakukan. Sebagaimana diketahui bahwa langkah penutupan tersebut didasarkan atas bukti-bukti ilmiah (scientific evidence) yang akurat, sedangkan ketersediaan data tersebut dewasa ini dapat dikatakan belum memadai.

Berkenaan dengan anggapan bahwa ikan kakap merah di Laut Arafura merupakan satu unit stok sehingga dikelola secara bersama, ada pendapat lain bahwa jenis Pristipomoides multidens di kawasan Laut Arafura merupakan mega separate stock (Lloyd et al., 1996). Selanjutnya, Cushing (1968) in Gulland (1983) mendefinisikan satu unit stok adalah ikan yang berasal dari satu daerah pemijahan di mana ikan dewasanya kembali lagi dari tahun ke tahun berikutnya. Kelompok ikan dapat diperlakukan sebagai satu unit stok jika tidak ada perbedaan dari parameter populasi.

Beberapa aspek yang perlu diteliti bagi tersedianya informasi tentang kemungkinan adanya stock separation menurut Gulland (1983) adalah: 
1. Daerah pemijahan. Dari survei yang dilakukan di Darwin, Gove, dan Weipa di Australia Utara dan Sape di kawasan timur Indonesia, juvenile ikan Lutjanus erythropterus dan Lutjanus malabaricus ditemukan di sekitar pantai, pada air yang keruh, berlumpur atau pada substrat pasir kasar, dan struktur rendah seperti coral rubble. Pada perikanan pukat udang Teluk Carpentaria juga dikatakan tertangkapnya dalam jumlah yang sedikit ikan kakap merah umur nol tahun pada tahun 1996 dan 1998 pada perairan yang lebih dalam. Informasi yang sama perlu diperoleh melalui kegiatan survei atau penelusuran referensi bagi kawasan perairan lainnya di Indonesia seperti di Merauke, Tual, Timor, dan kawasan timur Indonesia lainnya.

2. Nilai parameter populasi (antara lain pertumbuhan dan mortalitas). Jika terdapat perbedaan stok dan jika perbedaan tersebut cukup penting, maka ada perbedaan paling tidak dalam parameter populasi. Dari uraian terdahulu dapat diketahui adanya perbedaan parameter populasi ikan kakap merah yang menghuni perairan Arafura sektor Australia dan Indonesia. $\mathrm{Hal}$ ini diduga terkait dengan tingkat kesuburan Laut Arafura yang sangat tinggi dibandingkan dengan kesuburan perairan sektor Australia. Aspek dinamika populasi ikan kakap merah terutama terkait dengan parameter populasinya perlu diidentifikasi, terutama bagi jenis-jenis ikan yang tertangkap atau dijumpai di kawasan Laut Arafura sektor Indonesia.

Jika informasi terkait dengan parameter populasi ataupun aspek life history lainnya sudah terkumpul, tentunya akan merupakan salah satu dasar bagi ditetapkannya langkah pengelolaan yang tepat (proper management measures) dalam rangka memperoleh manfaat yang optimal dan berkelanjutan.

\section{KESIMPULAN}

1. Sumber daya ikan kakap merah di Laut Arafura secara efektif dimanfaatkan oleh perikanan rawai dasar, pukat ikan, dan pukat udang skala industri. Adanya fenomena genetic similarity ikan kakap merah di Laut Arafura (sektor Indonesia dan Australia) telah mengarahkan pihak Australia untuk menyimpulkan bahwa kakap merah di kedua sektor Laut Arafura tersebut merupakan satu unit stok.

2. Pengelolaan pada dasarnya adalah pengendalian penangkapan (control of fishing) dan pengendalian upaya penangkapan (control of fishing effort). Jumlah upaya penangkapan (misalnya jumlah kapal) di Laut Arafura sektor Indonesia jauh lebih banyak dibandingkan dengan Australia. Apabila Indonesia menurunkan jumlah kapal sama dengan jumlah kapal di sektor Australia, maka potensi kerugian akan menjadi kenyataan.

3. Untuk itu, informasi terkait dengan parameter populasi yang akurat, distribusi dan aspek life history ketiga spesies ikan kakap merah tersebut sangat diperlukan sebagai dasar bagi langkah pengelolaan yang tepat (proper management measures) yang dilakukan oleh masing-masing negara.

\section{DAFTAR PUSTAKA}

Anonymous. 1999. Biology, fishery assessment, and management of shared snapper fisheries in Northern Australia and Eastern Indonesia. Project Document FIS/97/165. ACIAR. 43 pp. 
Badrudin \& Aisyah. 2009. Separate stock of red snapper exploitation and management in the Indonesian sector of the Arafura Sea. Indonesian Fisheries Research Journal. 15 (2) :81-88.

Blaber, S. J. M., C. M. Dichmont, R. C. Buckworth, Badrudin, B. Sumiono, S. Nurhakim, B. Iskandar, B. Fegan, D. C. Ramm, \& J. P. Salini. 2005. Shared stocks of snappers (Lutjanidae) in Australia and Indonesia: Integrating biology, population dynamics, and socio economics to examine management scenarios. Reviews in Fish Biology and Fisheries. 15: 111-127.

Food and Agriculture Organization. 2009. The State of World Fisheries and Aquaculture 2008. Food and Agriculture Organization Fisheries and Aquaculture Department. FAO-UN. Rome. 176 pp.

Fry, G., D. A. Milton, T. Van Der Velde, I. Stobutzki, R. Andamari, Badrudin, \& B. Sumiono. 2009. Reproductive dynamics and nursery habitat preferences of two commercially important Indo-Pacific red snappers Lutjanus erythropterus and Lutjanus malabaricus. Fish.Sci. 75: 145158.

Gulland, J. A. 1983. Fish Stock Assessment-A Manual of Basic
Methods. John Wiley \& Sons. New York. 223 pp.

Lloyd, J., J. Ovenden, S. Newman, \& C. Keenan. 1996. Stock structure of Pristipomoides multidens resources across Northern Australia. Fish. Res. Dev.Corp. Fish. WA, NT-DPIF, QDPI. Fishery Report No.49. 36+21 Tables. 28 App. 14 Figs.

Ramm, D. C. \& Y. Xiao. 1994. Demersal fisheries in Northern Australia. Australia's Northern Trawl Fishery. Fishery Report No.32/1994.

Ramm, D. C. 1996. Sustainable groundfish yields in the Arafura Sea. Report on a Scientific Exchange Visit to Institute of Oceanography. National Taiwan University. 6 pp.

Ramm, D. C. 1994. Estimation of biomass and fishery yield for snapper stocks in Northern Australian waters. Australia's Northern Trawl Fishery. Fishery Report No.32/1994.

Talbot, F. H. 1960. Notes on the biology of the Lutjanidae (Fisces) of the East African coast, with special reference to Lutjanus bohar (Forskal). Annals of the South African Museum. XLV: 549-573. 